\title{
A diabetic with high haemoglobin A1c due to persistent haemoglobin $\mathbf{F}$
}

\author{
H N Rajaratnam¹, M I Weerakkody ${ }^{2}$, M Weerasinghe $^{2}$, S Siriwardena4 \\ Sri Lanka Journal of Diabetes Endocrinology and Metabolism 2011; 1: 45-47
}

\begin{abstract}
Laboratory and patient-related factors can result in false glycated haemoglobin (HbA1c) measurements. Haemoglobin $(\mathrm{Hb})$ variants that interfere with laboratory readings is an important cause. We report a case of hereditary persistence of Fetal Haemoglobin manifesting as a falsely high HbA1c in a 35-year old patient with type 2 diabetes mellitus, whose high $\mathrm{HbA} 1 \mathrm{c}$ values persisted despite intensive anti-diabetic treatment. His fasting and postprandial blood glucose values as well as serum fructosamine level was incongruously low compared to $\mathrm{HbA} 1 \mathrm{c}$ values. The presence of fetal haemoglobin was confirmed by haemoglobin electrophoresis. This case highlights the importance of being aware of the factors that can influence laboratory $\mathrm{HbA} 1 \mathrm{c}$ measurements.
\end{abstract}

\section{Introduction}

Glycated haemoglobin $(\mathrm{HbAlc})$ is a widely used measure of glycaemic control. Haemoglobin $(\mathrm{Hb})$ variants can affect laboratory interpretations of $\mathrm{HbAlc}$, resulting in discordantly high or low values. We present a case of an $\mathrm{Hb}$ variant causing aberrantly high $\mathrm{HbAlc}$ values in a patient with diabetes, and review some of the factors that affect $\mathrm{HbAlc}$ measurements.

\section{Case report}

A 35-year old welder was referred to the endocrinologist by a general practitioner for the management and follow up of very poorly controlled diabetes mellitus. He had presented one month ago with a fainting episode elevated capillary blood glucose. He was started on Metformin and Glibenclamide after the confirmation of diabetes and later referred to the endocrinologist as his $\mathrm{HbAlc}$ was $70 \%$. He did not have a significant past medical history and had never required blood transfusions. However, he had a strong family history of diabetes, with both his parents and two other siblings affected from their early fifties. On examination he was an averagely built man who was not pale or icteric. He had a $2 \mathrm{~cm}$ hepatomegaly and a $4 \mathrm{~cm}$ splenomegaly. The rest of the clinical examination was unremarkable with no evidence of diabetic retinopathy or neuropathy.

His fasting blood glucose was $154 \mathrm{mg} / \mathrm{dl}$ and the post prandial blood glucose was $224 \mathrm{mg} / \mathrm{dl}$. However, his $\mathrm{HbAlc}$ was $70 \%$ which was discrepantly high compared to his blood glucose values. The HbAlc test was done by ion exchange high performance liquid chromatography (HPLC) using a Biorad D10 machine. The possibility of an erroneous $\mathrm{HbAlc}$ reading was considered. This was supported by a fructosamine level of $294 \mathrm{micmol} / 1$ (205$285 \mathrm{micmol} / \mathrm{l})$, which denoted only a slightly impaired glucose control. Since $\mathrm{Hb}$ variants are known to cause aberrantly high $\mathrm{HbAlc}$ values during laboratory testing, we considered a $\mathrm{Hb}$ variant to be a strong possibility in our patient who had hepatosplenomegaly. His $\mathrm{Hb}$ count was $15.2 \mathrm{~g} / \mathrm{dl}$ and the blood picture showed hypochromic microcytic red cells, numerous target cells, irregularly contracted cells and irregularly haemoglobinized cells suggesting a thalassaemia trait. His haemoglobin electrophoresis revealed that his haemoglobin consisted entirely of $\mathrm{Hb} \mathrm{F}$ (foetal haemoglobin) with no detectable $\mathrm{Hb} \mathrm{A}$ or $\mathrm{HbA} 2$. This was suggestive of hereditary persistence of foetal haemoglobin. Although he was a product of a consanguineous marriage a similar illness had not been diagnosed in any of his family members previously.

\section{Discussion}

This is an interesting presentation of an otherwise undetected hereditary persistence of haemoglobin $\mathrm{F}$ manifesting solely as a discrepantly high $\mathrm{HbAlc}$ value.

In healthy adults haemoglobin comprises $97 \%$ of $\mathrm{Hb} \mathrm{A}, 2.5 \%$ of $\mathrm{HbA} 2$ and $0.5 \%$ of $\mathrm{HbF}$. Fractionation of $\mathrm{Hb}$ A by chromatography identifies several minor peaks referred to as $\mathrm{Hb} \mathrm{Al}$ or fast $\mathrm{Hbs}$ which include $\mathrm{HbAla}$, $\mathrm{HbAlb}$ and $\mathrm{HbAlc}$. Glucose binds to haemogloin in a two step process, and as one is irreversible, once bound

${ }^{1}$ Consultant Physician and Endocrinologist, Nawaloka Hospital, Colombo, ${ }^{2}$ Senior Registrar in Endocrinology, National Hospital of Sri Lanka, National Hospital of Sri Lanka, ${ }^{4}$ Consultant Chemical Pathologist, Durdans Hospital, Colombo, Sri Lanka. 
it lasts through the lifespan of the red blood cell, approximately 2 to 3 months. The $\mathrm{N}$ terminal valine of beta chains provides the most common site of glycation within the haemoglobin tetramer, accounting for $80 \%$ of $\mathrm{HbA1}(1)$.

Hence $\mathrm{HbA} 1 \mathrm{c}$ is the most widely used to monitor glycaemic control during a period of approximately 3 months and strongly correlates with the mean blood glucose level. The Diabetes Control and Complications trial (DCCT) and the United Kingdom Prospective Diabetes Study (UKPDS) were large trials that demonstrated that $\mathrm{HbA} 1 \mathrm{c}$ levels are directly related to the risk of complications of diabetes, stroke and ischaemic heart disease $(2,3)$. As $\mathrm{HbA} 1 \mathrm{c}$ is also a strong predictor of new onset diabetes mellitus, the American Diabetes Association now recommends this test in the diagnosis of diabetes mellitus and for identifying pre-diabetes (4). The American College of Endocrinology (ACE) and American Association of Clinical Endocrinologists (AACE) perceive that $\mathrm{HbA} 1 \mathrm{c}$ should not be the primary criterion for the diagnosis of diabetes mellitus and that it should be used in conjunction with fasting plasma glucose and/or oral glucose tolerance tests (5).

As HbAlc is important as a diagnostic and monitoring tool, it is important to be aware of conditions that can affect laboratory $\mathrm{HbA} 1 \mathrm{c}$ values apart from plasma glucose levels. Conditions that cause increased cell turnover and reduced average life span of the red blood cells can lead to lower HbAlc values. These include active bleeding, haemolytic disease, haemoglobinopathies and myelodysplastic disease. A patient with renal failure and uraemia can have high concentrations of carbamylated haemoglobin, resulting in aberrantly high $\mathrm{HbA1C}$. Falsely elevated $\mathrm{HbA} 1 \mathrm{c}$ measurements may also be obtained when red blood cell turnover is low, resulting in higher proportions of older red blood cells, such as in iron, B12 or folate deficiencies. Haemoglobinopathies can affect HbAlc values in three ways, they can influence the binding of glucose to haemoglobin, affect the peak measurements on chromatography and increase the risk of haemolysis and hence decrease the lifespan of red blood cells (6).

There are several commonly available methods to calculate HbA1c such as cation exchange chromatography, boronate affinity chromatography and immunoassay methods. Glycation alters the structure of the haemoglobin molecule and decreases its positive charge. Cation exchange chromatography separates haemoglobin species based on charge difference. Hb species are eluted from the cation exchange column at different times with the application of buffers of increasing ionic strength. A spectrophotometer measures the concentration of $\mathrm{Hb}$ in each column which is then quantified by calculating the area under each peak. The HbAlc percentage is then determined by an equation which includes $\mathrm{HbA}$ and
HbAlc values (1). Ion exchange high performance liquid chromatography (HPLC) method, which was the method used for our patient by the Biorad D10 machine uses similar principles.

Carriers of variant $\mathrm{Hbs}$ that elute separately from $\mathrm{HbA}$ and $\mathrm{HbA1c}$ theoretically should have little effect on the HbA1c measurement as they have little effect on the equation. However, several reports have indicated that $\mathrm{Hb}$ variants and elevated $\mathrm{HbF}$ levels can interfere with some HbAlc assays (1). However, only a few studies are available. One such study showed that ion exchange HPLC methods show only very minimal evidence of interference from elevated $\mathrm{HbF}$ levels even when the $\mathrm{HbF}$ levels exceed $15 \%$ (7). As our patient had $100 \%$ of $\mathrm{HbF}$ it probably interfered with the spectrophotometry of haemoglobin columns and gave the erroneous $\mathrm{HbA} 1 \mathrm{c}$ value. Although it was previously thought that the boronate affinity method was not affected by haemoglobin variants, the previously mentioned study showed that the presence of $\mathrm{HbF}$ artificially lowered the HbAlc values by this method as well (7). International Federation of Clinical Chemistry (IFCC) Reference Method (IFCC RM) for HbA1c measures glycated and nonglycated hexapeptides from $\mathrm{HbA} \beta$ chains. Because $\mathrm{HbF}$ has no $\beta$ chains, $\mathrm{HbF}$ does not cause interference with the IFCC RM because only the $\mathrm{HbA}$ terminal hexapeptides are measured. Therefore this method has minimal interference by $\mathrm{HbF}$ and can be used to asses gycaemic control in these patients (8).

When there are inconsistencies between a patient's home blood glucose monitoring and laboratory measured HbAlc, one should suspect a falsely elevated or lowered HbA1c result. Suspicion should also be raised when $\mathrm{HbAlc}$ is more than $15 \%$, or when there is a significant change in a patient's HbA1c when the laboratory assay method is changed (9). Comparing the patients home blood glucose monitoring values with his venous plasma glucose values would verify the accuracy of the blood glucose readings as opposed to the $\mathrm{HbAlc}$ value indicating the need to further evaluate a reason for the discrepantly high $\mathrm{HbAlc}$ value. Serum fructosamine level which reflects the average blood glucose control within the previous 2 to 3 weeks could also be used as a surrogate test. However the correlation between fructosamine and complications of diabetes mellitus has not been robustly evaluated in large randomised trials.

Elevated $\mathrm{HbF}$ levels can occur in patients as a result of pathologic conditions (eg, thalassaemia and leukaemia) or hereditary persistence of fetal haemoglobin (1). Approximately $1.5 \%$ of the US population has been reported to have elevated $\mathrm{HbF}$ levels as defined by an $\mathrm{HbF}$ level of more than $2 \%$ (10). Patients with the most common form of hereditary persistence of fetal haemoglobin can have $\mathrm{HbF}$ levels of up to $30 \%$, and because they are generally asymptomatic, patients and their physicians may be unaware of the existence of this 
condition (10). Our patient had $100 \%$ of $\mathrm{HbF}$ but was otherwise asymptomatic making hereditary persistence of foetal haemoglobin the most likely possibility in our patient.

In summary, this case illustrates the importance of maintaining a high degree of suspicion when the blood glucose values in a diabetic are incongruous with the $\mathrm{HbA1c}$ values. It also emphasizes the importance of using other biochemical parameters to diagnose and monitor glycaemic control in patients with haemoglobinopathies and haemoglobin variants.

\section{References}

1. Bry L, Chen PC, Sacks DB. Effects of hemoglobin variants and chemically modified derivatives on assays for glycohemoglobin. Clinical Chemistry 2001; 47: 153-63.

2. The DCCT Research Group. The effect of intensive treatment of diabetes on the development and progression of long term complications in insulin-dependent diabetes mellitus. New England Journal of Medicine 1993; 329: 977-86.

3. UK Prospective Diabetes Study Group. Intensive blood glucose with sulphonylureas or insulin compared with conventional treatment and risk of complications in patients with type 2 diabetes. Lancet 1998; 352: 837-53.

4. American Diabetes Association Clinical Practice Recommendations. Executive summary: standards of medical care in diabetes - 2010. Diabetes Care 2010; 33 (suppl 1): S4-5.

5. Rodbard HW, Jellinger PS, Davidson JA, et al. Statement by the American Association of Clinical Endocrinologists/ American College of Endocrinology Consensus Panel on Type 2 Diabetes Mellitus: an algorithm for glycemic control. Endocr Pract. 2009; 15(6): 540-59.

6. Ng HL, Koh CK. Aberrantly high glycated haemoglobin measurement due to the haemoglobin variant $\mathrm{Hb}$ Santa Juana. Singapore Medical Journal 2011; 52(4): e75.

7. Rohlfing C, Connolly S, England J, et al. The effect of elevated fetal hemoglobin on hemoglobin Alc results five common hemoglobin Alc methods compared with the ifcc reference method. American Journal of Clinical Pathology 2008; 129: 811-4.

8. Randie R, Roberts WL. A review of variant hemoglobin interfering with hemoglobin A1c measurement. Journal of Diabetes Science and Technology 2009; 3: 446-51.

9. Schrot RJ, Patel KT, Foulis P. Evaluation of inaccuracies in the measurement of glycaemia in the laboratory, by glucose meters, and through measurement of hemoglobin A1C. Clin Diabetes 2007; 25: 43-9.

10. Bunn HG, Forget BG. Hemoglobin: Molecular, Genetic, and Clinical Aspects. Philadelphia, PA: Saunders; 1986: 381-451. 